\title{
Impact of Western Sanctions on Russia in the Ukraine Crisis
}

\author{
Wan Wang ${ }^{1,2}$ \\ ${ }^{1}$ School of Government, Beijing Normal University, China \\ ${ }^{2}$ School of International Relations, Saint-Petersburg State University, Russia \\ Correspondence: Wan Wang, School of Government, Beijing Normal University, China. E-mail: \\ wwhmj1988@gmail.com
}

Received: February 17, 2015 Accepted: February 27, 2015 Online Published: March 26, 2015

doi:10.5539/jpl.v8n2p1 URL: http://dx.doi.org/10.5539/jpl.v8n2p1

\begin{abstract}
The year 2014 is an important and challenging year for Russia. The Ukraine crisis and Russia's Crimea annexation have pushed Russo-Western relations to near the freezing point. International sanctions against Russia led by the US and Europe have hindered the development of Russian economy. Despite facing these sanctions, domestically, Russia is politically stable, and its population is united. Diplomatically, Russia has accomplished great progress and forged strong relations with Asian countries, and its relationship with the East has continued to deepen. In experiencing Western hostility but Eastern friendliness, Russia mitigates the damage caused by the sanctions.
\end{abstract}

Keywords: western sanctions, Russia, Ukraine crisis, impact

\section{Introduction}

Throughout history and in the present day, Ukraine is of special and important significance to Russia. Favorably positioned between Russia and the West, Ukraine is in a unique strategic position. Ukraine is divided by the Dnieper River serving as the boundary between the pro-Russian eastern parts and the pro-European western parts. The current internal division has made Ukraine the focal point of the conflicts between Russia and the US-Europe. To maintain a strategy of geopolitical pressure on Russia, the US and the EU need to drag Ukraine into their bloc. Russia, in turn, must try its best to keep Ukraine to cushion the strategic pressure from the EU and NATO so that Russia will not lose its counterbalancing of the NATO frontier.

The Ukraine crisis in 2013 occurred precisely on this very background, evolving from a domestic coup to a global impactful international event. The Ukraine crisis has become a hot topic of concern over the past year in the field of international relations. The Ukraine crisis triggered Russia's annexation of Crimea, worsened East-West relations and caused multiple rounds of sanctions against Russia by the West, which have had a significant impact on Russia.

In this article, we analyse the impact of western sanctions in Ukraine crisis on Russia using literature, official data and opinion polls. First, the Ukraine crisis and the events of Russia's annexation of Crimea are reviewed. Then, the sanctions against Russia imposed by the West and Russia's anti-sanction measures are examined. Last, the impact of the sanctions on Russia's domestic and diplomatic strategies is analysed.

\section{Ukraine Crisis and Russia's Annexation of Crimea}

The crisis began on November 21, 2013, when Viktor Yanukovych, then President of Ukraine, suspended the signing of association agreement with EU to vie for Russian favor, which aroused opposition protests in Independence Square in Kiev, the capital of Ukraine. After the Ukrainian government ordered the expulsion of the protesters, the demonstrations escalated sharply and spread to other cities in Ukraine, directly pointing at Yanukovych and asking him to step down. On February 21, 2014, under the mediation of representatives from the EU and Russia, Viktor Yanukovych and opposition leaders signed the "Ukraine crisis mediation agreement". However, the opposition violated the agreement on the signing day and seized power by force. Yanukovych fled to Kharkov, and the next day, Ukraine's parliament appointed Turchinov, the speaker of the parliament, as the acting president (Liu Fenghua, 2014).

The coup that occurred in Kiev sparked unrest elsewhere in Ukraine. In areas that are inhabited by ethnic Russians, especially in the Autonomous Republic of Crimea where separatists dominate the population, protests 
against the new regime broke out. On March 2, under authorization to use force against Ukraine, Putin sent troops to Crimea. On March 16, the Autonomous Republic of Crimea held a referendum to determine its ownership. The referendum contained two choices: "Do you support the reunification of Crimea with Russia with all the rights of a federal subject of the Russian Federation?" and "Do you support the restoration of the Constitution of the Republic of Crimea in 1992 and the status of the Crimea as part of Ukraine?" (The State Council of the Republic of Crimea, 2014, March 6). Sevastopol City also participated in the referendum. Voting results showed that $96.77 \%$ of the voters in the Autonomous Republic of Crimea and $95.6 \%$ of voters in Sevastopol City were in favor of splitting off from Ukraine and joining Russia (The State Council of the Republic of Crimea, 2014, March 17; Crimea Online Obscuresque Referendum, 2014, March 17). The referendum results have been rectified by the Parliaments of the Autonomous Republic of Crimea and Sevastopol City. On March 18, Putin and the leaders of Crimea and Sevastopol signed the "Treaty on the Accession of the Republic of Crimea to Russia". On March 21, Putin signed the relevant treaties of reunification of Crimea and Sevastopol with Russia that had been approved by the State Duma, thus completing the legal proceedings of the reunification of Crimea and Sevastopol with Russia. The United Nations General Assembly held a vote on the Crimea referendum; 100 countries refused to recognize the referendum result, while 11 countries did recognise the result.

Thereafter, in the three pro-Russian regions of Donetsk, Luhansk and Kharkiv in eastern Ukraine, fights between pro-Russian and anti-Russian forces broke out. On July 17, when flying through Ukrainian airspace near the Russian border, Malaysia Airlines MH17 flight was shot down. This event not only reflected the severity of the conflict in eastern Ukraine but also intensified tensions in Ukraine. In addition, both Russia and NATO strengthened their military forces around Ukraine, including deploying troops and holding military exercises. On September 5, Ukraine, Russia, OSCE and representatives of anti-government armed forces from eastern Ukraine reached a ceasefire agreement in Minsk, the capital of Belarus. A memorandum was signed on September 19 in an attempt to end the five-month-old conflict. However, little change had been introduced to the unrest in eastern Ukraine. As of December 15, the armed conflicts in eastern Ukraine had caused at least 4,707 deaths with more than 10,000 people wounded (Xinhua, 2014, December 26). The game played in eastern Ukraine between Russia and the US-Europe had been affecting the evolution of the situation in the region.

\section{Sanctions and Anti-sanctions}

After Russia's annexation of Crimea, the US and the EU expressed strong opposition and accusations and then launched a series of sanctions against Russia. Undeterred, Russia had taken several anti-sanction measures.

From March 2014 to this writing, the US and Europe have implemented six rounds of sanctions, participated in by the US, the EU, Australia, New Zealand, Canada and Japan. The first three rounds of sanctions mostly targeted individuals or institutions, primarily through freezing their assets. A blacklist of sanctions, including the core leadership of Russian officials, businessmen and lawyers, was produced. The assets of these personnel in the sanction-enforcing countries were frozen, and their access to these countries was forbidden.

The first three rounds of sanctions did not produce any substantial effect. To further force Russia to abandon Crimea and change its behavior of destabilizing the eastern regions of Ukraine, on July 31 and September 5, 2014, the Member States of the Permanent Representatives Committee of the EU imposed another two rounds of substantive sanctions that added restrictions on the energy, finance and defence sectors of Russia and limited its financing in the US and Europe. With respect to energy, EU and US companies were banned from cooperating with Russian energy companies. Russia's three major oil companies, i.e., Sibneft of Gazprom, the Russian oil transportation company and Rosneft, were prohibited from issuing financing products that have terms longer than 30 days. Financially, the deadlines of bonds, stocks and other financial products from five Russian state-owned banks, i.e., the Bank of Moscow, VTB, the Russian Agricultural Bank, Gazprom and the Russian State-owned Development Bank, were shortened to 30 days; companies in the EU were prohibited from providing loans to the above-mentioned banks. With respect to defence, parts of Russian military enterprises were banned from accessing financing, the transport weapons and the transfer of sensitive technologies from the US and Europe. The US also froze the assets of five of Russia's defence technology companies in the US.

In December, the US and Europe launched a new round of sanctions against Russia. On December 18, the EU announced that trade and investment in Crimea and Sevastopol would be banned and that travel agencies would be prohibited from conducting business in Crimea beginning on December 20. One day later, President Obama signed authorizations of statutes for additional sanctions against Russia that prohibited US companies from doing business in Crimea.

Facing these increasing sanctions, Russia has taken retaliatory measures. At the beginning of the US and 
European sanctions, Russia raised the price of natural gas in Ukraine to exert pressure on Ukraine and reduced natural gas exports to Poland, Slovenia and Romania. With respect to agricultural product imports, in August 2014, Russia banned imports of meat, fruits, vegetables, and dairy products from countries that participated in the sanctions against Russia, including the US, Canada, Australia, Norway and the EU. Connecting flights on Ukraine Airlines were banned from flying through Russian airspace. In addition, Russia also warned that it might also shut down its airspace to airlines from countries that had participated the sanctions against Russia, prohibiting those airlines' flights from flying through its airspace. On December 1, 2014, while visiting Turkey, Russian President Vladimir Putin remarked that Russia would abandon the construction of the "South Stream" gas pipeline that transports gas to Europe via the Black Sea and would instead plan to invest in the construction of a natural gas pipeline leading to southern Europe via Turkey, increasing its cooperation on natural gas with Turkey and providing a $6 \%$ discount.

\section{Analysis of the Impacts}

The impacts include two parts, the domestic influences on Russia and the impacts on Russia's diplomatic strategy.

\subsection{Domestic Influences}

The domestic impacts on Russia can be divided into the following three aspects:

\subsubsection{The Sanctions against Russia Have Caused a Significant Impact on Russia's Economy}

Under the sanctions, from early 2014 to the present, the ruble-dollar exchange rate has fallen by nearly $50 \%$; on December 16, the rate plummeted $20 \%$ in just one day. Russia's domestic inflation rate has been as high as $11.4 \%$. Devaluation of the ruble against the dollar has been largely caused by falling oil prices. Russia's oil and gas-related revenue accounts for approximately $50 \%$ of revenues. The US and European countries specifically targeted Russia's heavy revenue dependence on oil and gas exports and focused their sanctions on the oil industry. The international price of oil price has dropped from to $\$ 115 /$ barrel in 2014 to the current price of approximately $\$ 50 /$ barrel; oil prices plunged precipitously this past December, severely impacting Russia's heavy reliance on oil exports. Russia's foreign exchange reserves have decreased to $\$ 416$ billion. In 2014, Russia's capital outflow reached nearly $\$ 130$ billion; the Bank of Russia predicted that the capital outflow in 2015 would be approximately $\$ 120$ billion (Expert Onlin, 2014 December 11). Because the sanctions against Russia's energy, finance and defence sectors have caused tremendous capital outflows and plummeting foreign exchange reserves, the Russian economy has been gravely affected; in October 2014, the international credit rating agency Moody lowered Russia's sovereign credit rating from Baa1 to Baa2. Since 2011, Russia's annual gross domestic product (GDP) growth rate has shown a downturn. Under the impact of the sanctions, Russia's GDP growth in 2014 was not very optimistic at all, being merely $0.2 \%$ according to the estimate by the International Monetary Fund (IMF), $0.5 \%$ according to the Organisation for Economic Co-operation and Development (OECD) and 0 according to the European Bank for Reconstruction and Development (EBRD). Russian experts have estimated the losses caused by the sanctions at approximately $\$ 4-5$ billion per year (Inozemtsev, 2014, December 1). Economic officials believe that the long-term severe sanctions may shake the financial system and limit scientific and technological modernization due to the restrictions in technology introduction, investment and application (Yurgens, 2014, October 9).

\subsubsection{The Sanctions Have Caused No Impact on Russia's Domestic Politics}

The US- and EU-led sanctions against Russia have inspired strong patriotism and nationalism in Russians. Rather than shake the public's support for the government, the sanctions have helped the government to mobilize its citizens. As phrased by Igor Yurgens, the President of the Russian think tank Institute for Contemporary Development, "Sanctions do not destabilize Russia's regime; on the contrary, they help Putin mobilize nationalism among the political elites" (Yurgens, 2014, October 9).

With the development of the Ukraine crisis, the support rate for Russian President Vladimir Putin has soared and stabilized at a high level. The data released by the Levada Center, a Russian public opinion research institute, show that support for President Vladimir Putin among the Russian population in 2014 has generally continued on an upward trend, averaging at $81.5 \%$, which is 18.0 and $15.75 \%$ higher than in $2013(63.5 \%)$ and 2012 (65.75\%), respectively. Since Russia's annexation of Crimea in March, the support rate for Vladimir Putin in Russia has soared and has been stable at $80 \%$, reaching its highest value at $88 \%$ in October (Levada Center).

At the same time, the unity of the Russian people has also steadily been increasing. Public opinion polling data released in November by the Russian polling research firm the Levada Center show that $68 \%$ of Russians believe that their country is a superpower, while this percentage was only $14 \%$ in the polls in March (Levada 
Center, 2014, December 11).

\subsubsection{The Sanctions Have Not Led Russia to Change Its Position on the Issues of Ukraine and Crimea}

Vladislav Inozemtsev, the director of the Russian think-tank the Post-Industrial Research Center, believes that the sanctions have not changed the status quo: Crimea is still under Russian control, while Russia's actions in eastern Ukraine are mostly in response to internal factors in Ukraine rather than as a reaction to the behavior of the West (Inozemtsev, 2014, November 15). A senior administration official in the White House admitted that, despite economic indicators showing that the sanctions have crippled the Russian economy, they have not changed the situation in Ukraine and Crimea to date. At a meeting with high-ranking military leaders on December 19, Putin vowed that Russia would never abandon the patriots who supported the Crimean peninsula (Boxun, 2014, December 21).

Some people have thought that Russia respected the election results in Ukraine by not responding to the request of Donetsk in eastern Ukraine for the reunification of Oblast to the Russian Federation that was proposed after the referendum, indicating that the US and European sanctions have played a certain deterrent role in Russia's attitudes and behaviors towards Ukraine (Jian Jisong \&Wang Hongxin, 2014). It is undoubtable that sanctions have had an impact to a certain extent. However, it should be noted that Russia might never intend to allow the pro-Russian cities in eastern Ukraine to duplicate the Crimean annexation and eventually join the Russian Federation. What Russia wanted probably was to maintain its influential power in the eastern region of Ukraine.

The international sanctions led by the US and Europe have hindered the development of the Russian economy. However, Russia still maintains political stability domestically, and Putin's support rate has been at all-time high levels; thus, Russia still adheres to its original positions on the Crimea and Ukraine issues.

\subsection{Impacts on Diplomatic Strategy}

The impact of the sanctions has prompted Russia to shift its diplomatic strategy toward the East. Western countries continue to impose sanctions on Russia, forcing Russia to adjust its diplomatic strategy and turn to Asia, e.g., China, India, Vietnam and North Korea, to seek new cooperation with Asian countries to avoid the diplomatic isolation brought about by the US and Europe and to mitigate the negative impacts of the sanctions.

\subsubsection{Russia and China}

China and Russia are both members of the United Nations, G20, Shanghai Cooperation Organization and the BRIC countries, sharing many common strategic interests. Russia seeks cooperation with China, which matches China's interest in the "Silk Road Economic Belt" proposed and vigorously promoted by President Xi. Over the past year of 2014, high-level officials have visited frequently between China and Russia, which has strengthened the countries' cooperation in the fields of foreign affairs, energy, finance, the military, science and technology, etc.

During May 20-21, Russian President Vladimir Putin was invited to China for a state visit and to attend the Conference on Interaction and Confidence-Building Measures in Asia (CICA) summit. In an interview prior to his visit, President Vladimir Putin said: "To expand cooperation with China is the prioritized direction of development for Russian diplomacy." Thereafter, the two leaders met in Shanghai and signed and issued the "People's Republic of China and the Russian Federation Joint Declaration on a new stage of comprehensive strategic partnership" (Xinhua, 2014, May 20). In addition, the two sides reached a "Memorandum on China-Russia Natural Gas Cooperation Project at the East Line", and the China National Petroleum Corporation and Gazprom signed the "Sino-Russian east gas purchase and sales contracts", in which it was agreed that from 2018 onwards, Russia would begin to provide natural gas through the east gas pipeline and that the volume of the gas supply would increase over time, eventually to reach 38 billion cubic meters per year (People Daily, 2014, May 22). This agreement marked a major breakthrough in the cooperation between China and Russia in the energy sector.

On October 13, the Prime Ministers of China and Russia met on their nineteenth regular meeting in Moscow and signed nearly 40 important cooperation documents involving trade, investment, energy, finance, technology, and humanitarian efforts, among others, including a currency swap agreement worth 150 billion yuan and the "Moscow-Kazan" high-speed railway development cooperation memorandum (People Daily, 2014, October 14). The VTB, Russia's State Development Bank and the Agricultural Bank of Russia signed framework agreements with the China Exim Bank on opening credit lines.

In addition, China and Russia have also strengthened their cooperation in the military and in technology. During May 22-26, China and Russia held a "joint maritime-2014" military exercise in the East China Sea. In November, during the eleventh Air Show held in Zhuhai, China, the China North Industries Group and the Russia Glasgow 
Jonas Group agreed to plan to form a joint venture to forge a cooperation in the field of satellite navigation.

\subsubsection{Russia and India}

From July 2014 to this writing, Russia and India have held a number of "Indra-2014" joint sea, land and air military exercises. In addition, Russia and India are planning to build an oil pipeline at a cost of up to $\$ 300$ million, en route to China's Xinjiang province (Kundu, 2012, October 11). In December 2014, Russian President Vladimir Putin visited India, and during his trip, Russia and India signed 25 bilateral cooperation documents related to the fields of energy, aviation, chemicals, finance, telecommunications, automotive manufacturing, etc. One conspicuous agreement was Russia's invitation to the Indian Oil Corporation to explore and exploit oil and gas resources in Siberia and Yamal and to participate in the development of the Arctic Continental Shelf and the liquefied natural gas plant project in the Far East (Voice of Russia, 2014, December 14).

\subsubsection{Russia and Vietnam}

On November 24, 2014, Nguyen Phu Trong, the General Secretary of the Central Committee of the Communist Party of Vietnam, visited Russia and met with Russian President Vladimir Putin in Sochi, where the two sides issued the "Joint Statement to advance the comprehensive strategic partnership between Russia and Vietnam" and signed a series of documents on the countries' cooperation in the fields of energy, trade, communications, technology and media, etc. For example, Gazprom and Petrovietnam will set up a joint company to develop the Dulkinski oil field in Russia, and Gazprom has agreed to export Eastern Siberia-Pacific Ocean (ESPO) crude oil to Vietnam (Guancha, 2014, November 27). In addition, Putin said that the negotiations on the establishment of a free trade zone between Vietnam and the Customs Union member states had entered the final stage.

\subsubsection{Russia and North Korea}

In April of 2014, Russian Deputy Prime Minister Trutnev visited North Korea. In May, Putin signed a bill to cancel 90 percent of North Korea's debt to the former Soviet Union, a total of approximately $\$ 10$ billion. Starting in June of 2014, Russia and North Korea agreed to use the ruble as the trade settlement to promote economic and trade cooperation between the two countries, and North Korea agreed to simplify the visa-issuing protocol for Russian citizens who are investing or working in North Korea.

\section{Discussion}

Russia will not change its targets related to its core interests. Russia cannot lose influence in Ukraine, at least not in letting Ukraine be a one-sided ally to the west. Therefore, on the Crimea and Ukraine issues, Russia will not give up its position, which is bound to prompt the US and Europe to continue to impose sanctions against Russia and to intensify the antagonism between Russia and the West. As stated by President Barack Obama at the quarterly Business Roundtable meeting on December 3, 2014, "But if you ask me if I'm optimistic that Putin suddenly changes his mindset, I don't think that will happen until the politics inside Russian catch up with what's happening in the economy, which is why we are going to continue to maintain that pressure." "The challenge is [that] this is working for him politically inside of Russia, even though it is isolating Russia completely internationally" (Expert Online, 2014, December 3). Thus, Western sanctions against Russia will not end any time soon, which will continue to undermine US-Russian relations, which were uncertain even before the Ukraine crisis. Currently, the EU stands in a united front with the US to impose sanctions against Russia. However, as the negative consequences of Russia's retaliatory measures against the EU become increasingly serious, the outcries to end the sanctions within the EU will get louder, and the EU may lose interest in the sanctions against Russia along with the US. Ultimately, on the Ukraine and Crimea issues, certain compromises between Russia and the US-Europe must be reached; nevertheless, the US's containment of Russia will not end soon.

\section{Funding}

This essay is phased achievement of project funded by State Key Laboratory of Hydroscience and Engineering Tsinghua University (sklhse-2014-A-03), National Social Science Fund project (14BGJ039), project funded by Beijing Philosophy and Social Science Planning Office (13KDB039) and the Fundamental Research Funds for the Central Universities

\section{References}

Boxun. (2014, December 21). Putin ignored sanctions: Nobody could frighten Russia. Retrieved from http://www.boxun.com/news/gb/intl/2014/12/201412212215.shtml\#.VJmDEqAEE

Crimea Online Obscuresque Referendum. (2014, March 17). The Sevastopol city council took the decision to join Russia as a separate entity of the Federation. Retrieved from 
http://referendum2014.ru/news/gorsovet-sevastopolya-prinyal-reshenie-ovstuplenii-v-sostav-rossii-vkachest veotdelnogo-subekta-fe.html

Expert Online. (2014, December 3). Obama: the United States along with the EU will continue to exert pressure on Russia. Retrieved from http://expert.ru/2014/12/3/obama-ssha-sovmestno-s-es-prodolzhat-okazyivat-davlenie-na-rossiyu/

Guancha. (2014, November 27). Russia and Vietnam planned to build free trade area. Retrieved from http://www.guancha.cn/Neighbors/2014_11_27_301718.shtml

Inozemtsev, V. (2014, December 1). How will sanctions change Russia. Retrieved from http://russiancouncil.ru/inner/?id_4=4885\#top

Inozemtsev, V. (2014, November 15). Russia and the West need a compromise over the Crimea. Retrieved from $\mathrm{http}: / /$ russiancouncil.ru/en/inner/?id_4=4792\#top

Jian, J. S., \&Wang, H. X. (2014). Analysis on US's economic sanctions against Russia from the perspective of legitimacy and implications for China. Law Review, 5, 6.

Kundu, N. D. (2012, October 11). Russia \& India Report.

Levada Center. (2014, December 11). 68\% of Russian consider Russia as a great power. Retrieved from http://www.levada.ru/11-12-2014/68-rossiyan-schitayut-rossiyu-velikoi-derzhavoi

Liu, F. H. (2014). Ukraine crisis: Internal facto, game of powers and prospect. Academic Journal of Russian Studies, 3, 12.

People Daily. (2014, May 22). Xi Jinping and Putin together witnessed the signing of Sino-Russian gas cooperation agreement. Retrieved December 8, 2014, from http://paper.people.com.cn/rmrb/html/2014-05/22/nw.D110000renmrb_20140522_3-01.htm

People Daily. (2014, October 14). The joint communique of nineteenth regular meeting between the prime ministers of China and Russia. Retrieved from $\mathrm{http}: / /$ paper.people.com.cn/rmrb/html/2014-10/14/nw.D10000renmrb_20141014_2-02.htm

The State Council of the Republic of Crimea. (2014, December 11). The Crimea Parliament adopted a resolution about holding the Crimean referendum. Retrieved from http://www.rada.crimea.ua/news/06_03_2014_1

The State Council of the Republic of Crimea. (2014, March 17). 96.77\% of voters support the Crimean referendum on 16 March 2014 for the reunification of the Crimea with Russia on the rights of the subject of the Russian Federation. Retrieved from http://www.rada.crimea.ua/news/17_03_2014_3

Voice of Russia. (2014, December 14). Russia and India agreed the roadmap of their strategic partnership. Retrieved from http://radiover.com.cn/2014_12_14/281267716/

Xinhua. (2014, December 26). Ukrainian authority and the eastern opposition leaders reached a prisoner exchange agreement. Retrieved from http://news.xinhuanet.com/world/2014-12/26/c_1113781279.htm

Xinhua. (2014, May 20). Sino-Russian joint statement: Comprehensive strategic cooperative partnership steps into a new stage. Retrieved from http://www.zijing.org/htmls/shizheng/607115.shtml

Yurgens, I. (2014, October 9). The West vs. Russia: The unintended consequesces of targeted sanctions. Retrieved from http://russiancouncil.ru/en/inner/?id_4=4532\#top

Эксперт Onlin. (2014, December 11). CB: the outflow of capital in 2015 will amount to $\$ 120$ billion in all scenarios.

Retrieved

from

http://expert.ru/2014/12/11/tsb-ottok-kapitala-v-2015-godu--sostavit-s120-mlrd-pri-vseh-stsenariyah/

\section{Copyrights}

Copyright for this article is retained by the author(s), with first publication rights granted to the journal.

This is an open-access article distributed under the terms and conditions of the Creative Commons Attribution license (http://creativecommons.org/licenses/by/3.0/). 